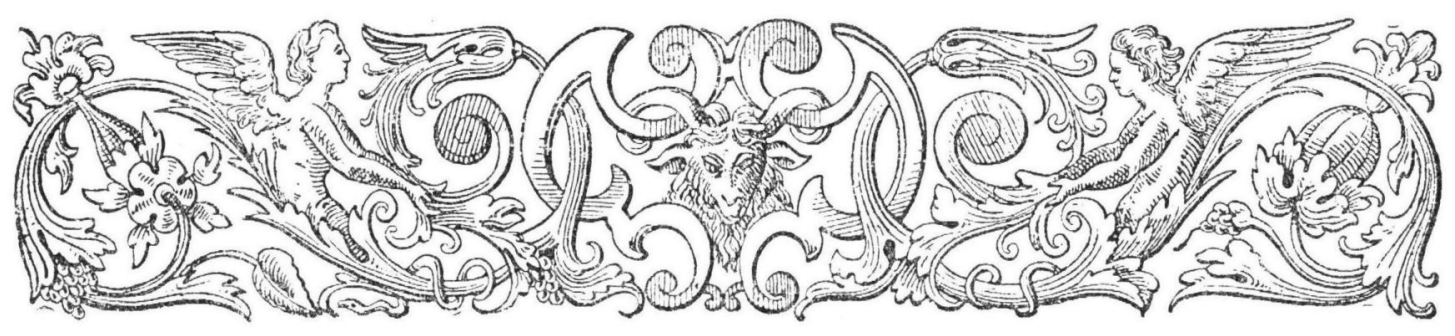

\title{
DE SCHILDERS CAMPHUYSEN
}

DOOR

DR. A. BREDIUS EN E. W. MOES.

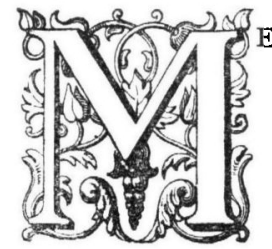

ET de schilders CAMPhuysen heeft zich een zonderling geval in de kunstgeschiedenis voorgedaan. Tot voor een kleine halve eeuw geleden zijn alle schilderijen die den naam CAMPHUySEN droegen of volgens overlevering door een CAMPHUYSEN geschilderd waren, toegeschreven aan een lid van die familie, die er part nog deel aan had, terwijl de werkelijke schilders onbekend bleven. Toch is deze fout, waarvan HoUBRAKEN zich het eerst de tolk gemaakt heeft, en die sedert in alle handboeken en catalogi verspreid is, wel te verklaren. Men kende algemeen den begaafden en gevoelvollen dichter DIRCK RAFELSZ. CAMPHUYSEN en van zijn avontuurlijk leven waren allerlei juiste en onjuiste verhalen in omloop. Daarbij wist men, dat hij voor schilder was opgeleid. En zoo was de weg gebaand waarlangs de verkeerde opvatting zich voortplantte. Om kritiek bekommerden de oude kunsthistorici zich weinig, HoubRAKEN het allerminst. Hij was de laatste om te bemerken, dat hij een groote dwaasheid neerschreef, toen hij beweerde, dat zijn held POTTER met geluk had nagevolgd; het kwam niet bij hem op, hoe bedenkelijk het was, dat een man die in 1627 was gestorven, iemand nabootste, die nog geen twee jaar te voren geboren was.

Oud-Holland, 1903. 
Eerst toen de verdienstelijke Amsterdamsche archivaris ScheltemA in 1858 aan het licht bracht '), dat er nog eenige andere CAMPHUysens geweest waren, die met het beroep "schilder" achter hun naam, in de Amsterdamsche huwelijksregisters geboekt waren, begon men na te denken. BURGER was ook hier weer de eerste, die in zijn onwaardeerbaar boekje over de Hollandsche musea ${ }^{2}$ ), den stier bij de hoorns vatte, en in 1860 de zaak trachtte te ontwarren. Hierin werd hij in 1867 gevolgd door T. VAN WESTHREENE Wz, die in zijn uitnemende biographie van PAULUS POTTER ook een hoofdstuk aan de CAMPHUYSEns wijdde, en in 1877 door EDOUARD FETIS, die toen in het tijdschrift L'Art ${ }^{3}$ ) een verdienstelijk artikel over de CAMPHUYSENS geschreven heeft, waarvan een uittreksel te vinden is in de Kunstkroniek ${ }^{4}$ ). Sedert zijn nog hier en daar, vooral door de nasporingen van A. D. DE VRIES Az. eenige nadere bijzonderheden bekend geworden, totdat in 1898 L. A. RADEMAKER in zijn voortreffelijke dissertatie over den dichter CAMPHUYSEN nogmaals het resultaat van aller onderzoekingen te boek stelde.

Wel was men onderwijl vrij algemeen bij het toedeelen van de schilderijen van den dichter afgestapt, maar toch bevatten nog alle korte biographieën in catalogi min of meer foutieve opgaven. Daarom achten wij het meer dan tijd, thans voor goed den staat van zaken aan de hand van archiefstukken en kunstwerken bloot te leggen, en zullen daarom achtereenvolgens de verschillende leden der familie behandelen, die het penseel gehanteerd hebben.

De eerste die ons van deze naar het schijnt aanzienlijke familie belkend geworden is, woonde te Gorinchem en was "een chyrurgyn, genaemt mr. RAFEL, een man van meer als gemeene konst en seer redelijk van oordeel, als oock van leeven, hij was om sijn hulpsaemheyt en minlijkheit van het gemeen seer bemind". Deze was gehuwd met Maria VAN MASEIK "van een sonderlinge godvrugtigheit onder de Doopsgesinten, aerdende na haar vader HANS vaN MASEIK, een coopman, die hem om de belijdenis des geloofs te Gorkum liet onthalsen" s).

Uit dit echtpaar zijn ons de namen van twee zoons bewaard, GoverT en Dirck, waarvan de eerste veel ouder geweest moet zijn dan de laatste, want

1) Navorscher VIII, p. I6.

2) W. Burger, Musées de la Hollande, II, Bruxelles I860, p. $23^{8-244}$.

3) L'Art, 1877, p. 37, 38, 63-67.

4) Kunstkroniek, Nieuwe Serie, I (I878), p. 28, 29.

5) Ms. Camphuysen, Rademaker p. 256. 
toen in 1594 de moeder stierf en de vader niet lang daarna, en DIRCK misschien den leeftijd van ongeveer tien jaar bereikt had, was GovERT, die hetzelfde vak als zijn vader beoefende, reeds gehuwd. Deze, den gunstigen aanleg van zijn jongeren broeder kennende, had hem in de leer gedaan bij den schilder

\section{DIRCK GOVERTSZ.}

Het komt ons niet onwaarschijnlijk voor, dat deze DirCK GoverTz., die de beide namen der broeders in zijn naam vereenigde, tot dezelfde familie behoorde, maar zekerheid hieromtrent konden wij niet verkrijgen. DIRCK GoverTSz. is trouwens ook als schilder nog vrijwel een onbekende.

De eenige keer dat hij in eenig archiefstuk genoemd is, was toen in 1627 te Gorinchem de kohieren van de haardsteden werden opgemaakt. Daarin komt „DIRCK Govertsz. schilder" voor met vier schoorsteenen „op het Westendt in het quartier van den Langen Dijck" I). HOUBRakEN noemt hem den meester van HENDRICK VERSCHURING. Dat verplaatst zijn werkzaamheid heel wat later, want diens leerjaren $b_{i j}$ hem vielen van zijn achtste tot zijn dertiende jaar, m. a. w. van omstreeks 1635 tot omstreeks 1640. En HOUBRAKEN noemt hem daarbij portretschilder. Maar hierbij dient opgemerkt, dat HouBRAKEN zijn biographie van Verschuring geheel ontleend heeft aan Roger de Piles' Abóégé de la vie des peintres, en deze spreekt slechts van "un peintre de Gorcum qui ne faisoit que des portraits". Dat die schilder DIRCK GoverTsz. heette, maakte eerst Houbraken er bij, en dat deze alleen portretten schilderde is beslist onjuist. Immers 27 Juni $16_{3} 6$ verbond de kerkschilder JOHANNES vaN Vucht zich, aan DAvid van HoogenHuysen te Amsterdam te leveren "een schilderij sijnde een keucken, gemaect naer een schilderij van Mr. Dirck Govertsz." 2). En in den inventaris van den inboedel van MARIA Rochatius, weduwe van CoRNELIS VAN BORCHAREN, Raad en Vroedschap van Gorinchem, opgemaakt in I698, vinden wij "In 't zalet. Een dito (d. i. schilderij) grooter, boven de kast, van DiRCK GoverTsz.", boven op de voorkamer „Twee stucken van DiRCK Govertsz." en op de achterkamer „Een dito met eenig wilt van DIRcK Govertsz." 3).

Tot op zijn achttiende jaar, dus tot omstreeks I604, bleef de jonge Dirck Rafelsz. Camphuysen bij dezen Dirck Govertz. „daar hij inde kunst seer avanceerde en scheen een uitsteeck in de selve te sullen worden; hij kon

\footnotetext{
Obreen's Archief VII, p. 309 .

Oud-Holland IX, p. 45 .

OrREen's Archief VII, p. 309, 3Io, 3Ir.
} 
soo aardig met de pen arceeren, dat hy meenig mensch met sijn teykeningen abuseerde, die het voor een prent aansaagen, gelijk ik selfs nog soo een in mijn hand heb gehad", enz. ').

Van nu af heeft de verdere levensloop van DiRCK Rafelsz. Camphuysen geen belang meer voor de kunstgeschiedenis.

Door zijn broeder voor de kunst te willen laten opleiden, had GOvERT blijk gegeven een open oog daarvoor te hebben. Geen wonder, dat toen hij zag, dat de poging bij DIRCK aangewend, niet gelukte en hij bespeurde dat zich ook bij zijn eigen kinderen dezelfde aanleg vertoonde, hij met hen hetzelfde probeerde. Twee kinderen zijn ons van hem bekend, RAFEL en Jochem. Met hen beiden was hij gelukkiger.

\section{RAFEL GOVERTSZ. CAMPHUYSEN}

was in 1597 of $\mathbf{I} 595$ geboren te Gorinchem. Het aantal schilders was daar zeker niet gioot, en niet onwaarschijnlijk is het, dat ook zijn leermeester DiRCK GOVERTSz. geweest is. Maar overgeleverd is ons noch van zijn leerjaren, noch van zijn werkzaamheid in zijn vaderstad iets, en wij vinden hem eerst terug wonende te Amsterdam in 1626, toen 24 Oct. van dat jaar daar de ondertrouw werd aangeteekend van: „RAPHel Camphuysen, van Gorkem, schilder, oud 28

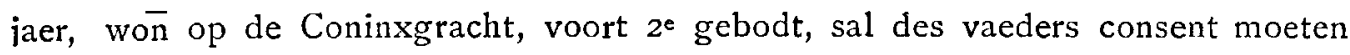
blycken, en MAChtelt Crose VAN HERsberghe out 32 jaer, geen ouders hebbende, geass. met haer nicht Sophia RANnix, won̄als voren. - GoverT RAEPhelsz. CAMPhuizen, de vader, verclaert te consenteeren in 't huwelyck voorz. - Nota dat dese personen getrouwt sijn tot Sloterdyck den I 5 Nov. i6 626 door Matthyas Meursius predicant te Sloterdyck" 2).

Het eenige kind uit dezen echt, waarvan wij melding gemaakt vonden, werd spoedig na de geboorte ten grave gedragen : "RAFEL CAMPIOUEN [schrijffout] achterburgwal, kind onder den arm, begraven in de Nieuwe Kerk 6 Oct. I627".

28 Dec. I642 was RAFel CAMPhuYsen te Amsterdam getuige bij den doop van Cornelia, een dochtertje van AERT van DER NEER ${ }^{3}$ ). Nog eenmaal vinden wij hem in een acte vermeld: I 2 Aug. 1657 verklaart RAPHAEL CAMphuysen, schilder, oud 58 jaren, dat Johannes VAN VRATUm "plaetsnijder en mutsedrucker" een eerlijk en braaf man is. ${ }^{4}$ ).

1) Ms. Camphursen, Rademaker, p. 256, 257 .

2) Oud-Holland, III p. 73 .

3) Oud-Holland III, p. 234.

1) Prot. Not. Johs. Hellerus te Amsterdam. 
23 Oct. 1657 werd in de Nieuwe Kerk begraven : „RAepiel Camphuysen,

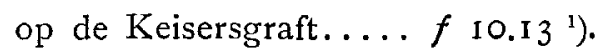

Met deze weinige archivalische gegevens moeten wij ons tevreden stellen'). $\mathrm{Er}$ is echter een belangrijke mededeeling bij. Hij hield in 1642 een kind van AERT VAN DER NEER ten doop, en was dus klaarblijkelijk bevriend met dien beroemden schilder van ijsgezichten, maneschijnen en branden. En nu is het wel opmerkelijk, dat RAFEL CAMPhUYsen juist in diezelfde genres zijn beste producten heeft geleverd. Maar hij was een jaar of vijf ouder dan VAN DER NEER. En Houbraken vermeldt, dat deze aanvankelijk „Majoor geweest is by de Heeren VAN ARKEL", dus te Gorinchem. Is de gevolgtrekking te gewaagd, dat CAMPhuysen de kiem gelegd heeft van het talent, dat zich in VAN DER NEER zoo schitterend heeft ontwikkeld?

Gaan wij nu na, wat er van de werken van Rafei, GQvertsz. Camphuysen overgebleven is. Helaas draagt geen enkel een jaarmerk. Maar tot zijn oudste werken behoort een viertal, dat stellig nog door hem te Gorinchem is geschilderd, want het werd aangetroffen in den boedel van den ouden Herman Saftleven, den vader der bekende schilders Cornelis en Herman Saftleven, die deze stukken zonder twijfel had door zijn Gorkumsche relaties. De inventaris van dezen boedel was opgemaakt in 1627 en de vier bedoelde schilderijen staan er in beschreven als "een Maanschijn van CAmphuIjse... $f 6$ gld., Een boom van Kamphuysen, Een maneschyn van Kamphusen, en Een brandeke van KAMPHUSEN': ')

Van zulke maneschijnen zijn twee zeer goede exemplaren in het Museum te Dresden, beide een dorp aan een rivier te zien gevend met de maan schijnend door de wolken. Ofschoon het eene duidelijk gemerkt is: R. CAMPHUIJSEN, en op het andere ook nog te onderscheiden is......PHUYSEN, werden ze sedert 1754 gecatalogiseerd als producten van ADRIAEN VAN DER CABEL, die NB eerst in $\mathrm{I} 6_{3} \mathrm{I}$ is geboren. $\mathrm{Na}$ den gebruikelijken overgang DIRCK RAFELSZ. CAMPHUYSEN gaf eerst KARL WOERMANN ze aan den waren meester terug. Op het eerste staan rechts huizen door boomen omgeven aan den oever en links een kerk en een molen, waarvoor onder de boomen eenige personen om een vuurtje staan. Op het andere staan rechts en links aan beide oevers huizen onder de

1) Oud-Holland III, p. 73 .

2) In een catalogus van de firma MART. Nijhoff te s Gravenhage kwam voor een „Request van THEOD. JORUSSEN aan de Magistraat van Harlingen om te mogen verloten eenige deftige schilderijen van zijn stijfzoon RaphaEl van CaMphuYsen, $I \epsilon_{4} 0$ fol". Met dezen stiefvader weten wij geen weg.

3) OBREEN's Archief V, P. I25, 129. 
boomen; hier staan kerk en molen rechts, terwijl in het midden een scheepje zeilt en links op den voorgrond onder hooge boomen een groepje personen om een vuurtje staat. Beide stukjes zijn $47 \mathrm{~cm}$. hoog en $631 / 2 \mathrm{~cm}$, breed, en op paneel geschilderd.

Daarentegen heette een rivierlandschap in het Museum te Brunswijk, dat slechts met de initialen R. C. gemerkt is, toen het nog in het slot te Saltzdahlum hing en ook later REyNIER COVyN. Op den voorgrond staat aan den rechter oever een visschershut waarbij visschers bezig zijn een bootje op het land te trekken en op den linkeroever iets meer op den achtergrond een groep huizen tusschen boomen; verschillende bootjes verlevendigen de rivier; op een weg spreekt een vrouw met een man die een mand op het hoofd draagt, terwijl anderen tonnen op het hoofd dragen; op den achtergrond steekt boven de boomen een toren uit (h. $39^{\frac{1}{2}}$ br. $55^{\frac{1}{2}}$, P.) ${ }^{1}$ ).

Evenzoo (R. C.) gemerkt is een winterlandschap in de Universiteit te Stockholm, gelegateerd door de Wed. HeLENA BerG-BLIGH. Rechts op den voorgrond strekt zich een groot dorp uit; vooraan een boerenhut tusschen de boomen, waarnaast een slede met twee figuren en een man die zijn schaatsen aanbindt. Op het ijs bewegen zich tal van figuurtjes. Op den achtergrond in het midden een met riet bedekte schuur en verder een toren en een windmolen (h. 53 br. 84 , P.).

En ook een landschap met badenden in het Museum Kunstliefde te Utrecht, waaraan het geschonken is door den heer G. A. G. F. Mollinger. Aan den voet van twee hooge boomen op den voorgrond links staan zeven personen gereed zich in het water te begeven; rechts een weide met koeien en boerenwoningen; op den tweeden grond een weg waarop een reiswagen en een chais en in het verschiet een stad (h. $51^{1 / 2}$ br. 82, P.).

Voluit gemerkt en fraaier is een klein landschapje in het Rijksmuseum te Amsterdam, afkomstig van de verk, coll. GIJsbert DE ClerCQ, Amsterdam I Juni 1897. Een weg voert naar een bruggetje dat toegang geeft tot een links gelegen boerderij; rechts strekken zich tot aan den horizon weiden uit, met in het verschiet een dorp; de ondergaande zon kleurt de lucht rood (h. 46 br. $63 \frac{1}{2}$, P.).

Evenzoo een landschap met een slapenden herder in het bezit van den schilder LENBACH te München. die het kocht uit de coll. RUPRECHT aldaar (h. 49 br. 63, P.), een landschap met een maneschijn in de Galerie te Schleisheim (h. 49 br. 63, P.), een winterlandschep met schaatsenrijders in de coll.

1) Het monogram is afgẻeeld bij H. RIEGEL, Beiträge zur niederländischen Kunstgeschichte, II, p. 354 . 


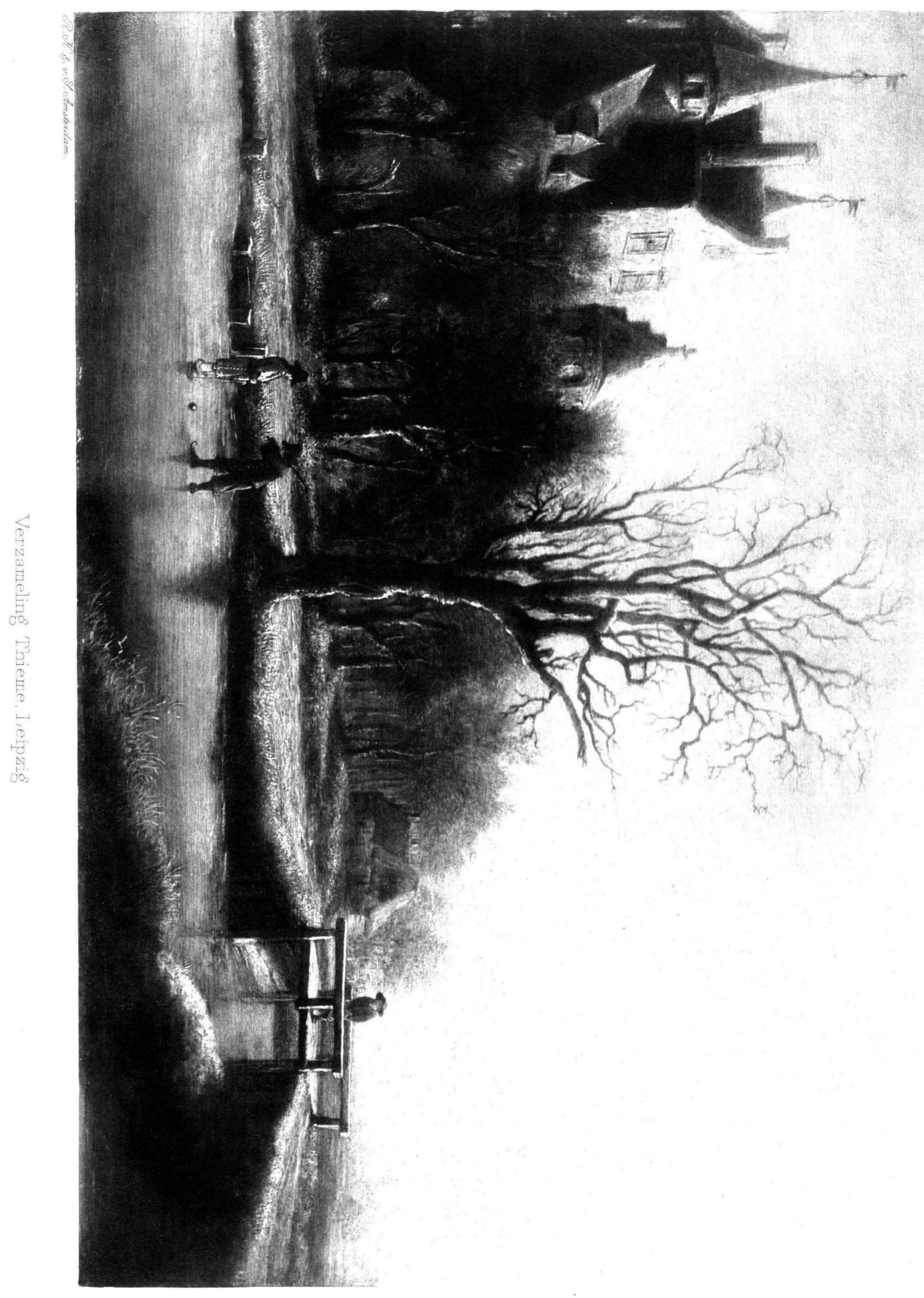

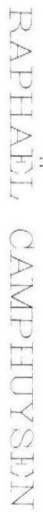


LIECHTENSTEIN te Weenen, voor 2850 Mark aangekocht op de verk. coll. PEIN uit Berlijn te Keulen 1888 , en afgebeeld in den veilingscatalogus, „Schön componirt, leuchtend und warm im Ton, fett und breit behandelt" noemde BODE het stuk, betuigende dat de meester ALBERT CuYP soms nabij komt ${ }^{1}$ ).

En een winterlandschap dat Consul ThIEme te Leipzig in 1887 van den kunstkooper MARTIN COLNAGHI te Londen gekocht heeft, "en dat zeer de aandacht getrokken heeft op de tentoonstelling van oude kunst, in I 889 te Leipzig gehouden (h. 48 br. 63, P.). Daar wij van dit prachtstukje een af beelding geven kan een beschrijving achterwege blijven. BODE die in het galerijwerk, dat de heer THIEME over zijn verzameling heeft uitgegeven een overzicht van de Hollandsche schildersschool geschrcven heeft, laat zich naar aanleiding van dit breed en vet gedaan werk, waarin vooral de lucht aan VAN DER NEER doet denken, aldus over den meester uit. „Ein Künstler, der unter den ersten in dieser Weise in Amsterdam die Landschaft behandelte, bald Waldeingänge, flache buschige Landschaften bei Abendlicht und gelegentlich auch Winterlandschaften malt, ist der in neuester Zeit wieder beachtete RAPHEL CAMPHUYSEN" "). Hoogstwaarschijnlijk, zoo niet zeker, is deze schilderij dezelfde die 2 I Juni I8I9 met het kabinet DE BURTIN te Brussel verkocht werd, en die FrançOIs XAvier DE BURTIN in 1805 beschrijft als in zijn bezit. Hij noemt er het kasteel achter de boomen Crayenburg tusschen den Haag en Delft. Ook hij was getroffen door de bijzondere qualiteiten van dit stukje, en ging zelfs zóó ver, te beweeren, dat hem maar één winterlandschap bekend was, waarin het den kunstenaar volkomen gelukt is, de monotonekleur van den sneeuw te verlevendigen door den gloed van de zon, en die ééne schilderij was deze CAMPhUYSEN ${ }^{3}$ ).

Ook op veilingen $k$ wamen in den laatsten tijd eenige gemerkte stukken van RAFEL CAMPHUYSEN voor, die aan den juisten meester toegeschreven waren, bv. op die van de coll. Houck uit Deventer, Amsterdam 7 Mei I895. Bij een riviertje, waarvoor een steenen bruggetje, staat een zeer vervallen boerenhuis; op den voorgrond rechts vraagt een bedelaar iets aan een heer; op den achtergrond links aan den overkant van het water steekt boven de boomen een kerktorentje uit en ziet men nog eenige woningen en een molen. Het stuk is gereproduceerd in den catalogus en werd voor $f 825$ gekocht door den kunsthandelaar KOEKKOEK te Londen (h. 47 br. 62, P.). En op de verk. coll. HöCH te München, 19 Sept I\$92. Links op den voorgrond kijken bij een zwaren boom een oud man en een oud vrouwtje naar de schaatsenrijders op de ijsvlakte; aan den overkant

1) Graphische Künste, XVII p. 94 .

2) Galerie Alfred Thieme in Leipzig, mit Einleitung von Wilhelm Bode herausgegeben von Ulrich THEME, Leipzig I900.

3) Fr. X. BURtin, Traité historique pratique etc., Bruxelles 1805, I, p. 24 , II p. I64, 165. 
staat rechts aan den oever een boerenhofstede en ziet men in het verschiet de huizen en de kerk van een stad (h. $38 \frac{1}{2}$ br. 43 , D.).

Naar aanleiding van deze gemerkte stukken was het niet moeielijk den schilder nog eenige andere toe te schrijven. Zoo draagt thans een landschap in het Museum te Aschaffenburg, dat vroeger onder de anonymen gerangschikt was, zijn naam. Het geeft een steenen sluis te zien waarover een herder drie runderen drijft; vooraan is een bootje met een fuik en een vrouw met twee kinderen en op den tweeden g.ond ligt aan het water een dorp met een koets vóór een herberg (h. 96 br. 139, D.). Ook de verzameling GLITZA te Hamburg bezit een winterlandschap, dat thans aan hem is toegeschreven. Kleine figuurtjes van schaatsenrijders, sleden en kolfspelers verlevendigen het tafereeltje (h. 39 br. 65, P.), en in de verzamelingen DAHL te Düsseldorf en Peltzer te Keulen bevinden zich eveneens dergelijke stukken, het laatste een maneschijn.

Gelijk van zelf spreekt was RAFEL CAMPhuysen tijdens zijn leven en kort daarna niet zulk een onbekende, als hij later geworden is, zoodat zijn naam nog al eens in oude inventarissen aangetroffen wordt, meestal als de schilder van maneschijntjes. In 1646 was bij FREDERICK Schoonsteen te Amsterdam "een stuck van RaphaEL "CAMphUYSEN", in 1666 werd in den boedel van JAN Claesz. VAN Gorcum, wonende te Amsterdam "een grootachtigh lantschap schildery van RAPHAEL CAMphuysen" op $f$ 8.- getaxeerd, in 1688 liet JACOB VALCKMaN ,een lantschapje door R. CAMPHUYSEN" na, in $\mathrm{I} 670$ hing bij Abraham Fabritius, in de keucken een maneschyntje van R. Camphuysen" en ,in de binnecamer agter "t voorhuys" een dergelijk schilderijtje, de 25 Nov. I67I overleden Amsterdammer NiCOLAEs vaN BAMBEECK had "twee maneschyntjes van CAMPhuyseN", en om nog één voorbeeld te noemen, in 1674 was in den boedel van Agatha Dolfyns, weduwe van Hendrick BEETs, te Amsterdam, „een maneschyn door R. Camphuysen”.

Vermoedelijk was hij de schilder van "een ouwerwets dogh fray lantschap van CAMphuysen, door Colyns gestoffeert", dat in 1687 voorkomt op den inventaris van den kunstkooper Hendrick MEyerinck te Amsterdam.

Minder gelukkig waren wij met onze nasporingen naar het leven en de werken van RAFEL's jongeren broeder

\section{JOCHEM GOVERTSZ. CAMPHUYSEN.}

Wat diens levensbijzonderheden betreft, zijn de gegevens nagenoeg gelijk aan die van RAFEL. Hij was te Gorinchem geboren in I60I of 1602 , vestigde zich omstreeks $162 \mathrm{I}$ te Amsterdam en huwde daar in 1627. Zijn ondertrouw 
op 20 Februari van dat jaar is als volgt geboekt: "Jochem CAMPhuysen, van Gorkum, out 25 jaer, geen ouders hebbende, schilder, geassisteert met RAPHEL CAMPHUYSEN, zyn broeder, woonende ( 6 annis) over de Gasthuysmeulenbrugh, en HEYNDRICKJE JACOBS, out 20 jaar, geen vaeder hebbende, geassisteert met haer moeder HaRmTJE HENDRIX, woonende aen de Heiligewechpoort. - Dese persoonen zyn getrouwdt den 7 Meert I627 tot Sloterdyck, door M. Meursius, Predt. aldaer" 1). Hoe met deze verklaring, dat HEYNDRICKJE JACOBS geen vader meer had, de acte in overeenstemming te brengen is, dat "JOCHEM CAMPHUXSEN, schilder" I 5 Februari I639 als man en voogd van HENDRICKJE JACOBS $f$ 500.erft van ЈАСОВ JANSZ, lijnslager, zijn schoonvader, begrijpen wij niet ${ }^{2}$ ). Nog weten wij wanneer hij stierf, want 2I Jan, I659 werd in de Nieuwe Zijds Kapel begraven: "Een man, Jochem CAmphuys, schilder, comt van het water, by die vrouwensteegh, int witte klaverblat; 2 kinder" ${ }^{3}$ ).

I I Juni I664 attesteert „HENDRICKJE VAN GELDER, wed. van sal. Jochum Camphuysen, in sijn leven schilder, out 58 jaren" over turf. Getuige was ${ }^{4}$ )
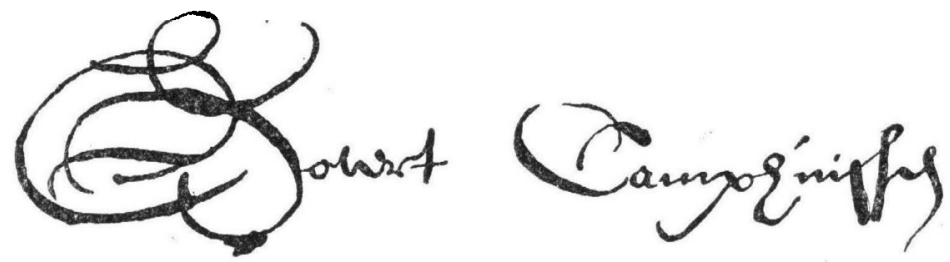

De weduwe overleed in het begin van Juli 1665. I 5 Sept. 1665 verklaart „AnNetje Berentsdr., out i 7 jaer, ten verzoeke van Margaretha Camphuysen, huijsvrouw van JACOB TIN, dat by deposante, op het Water, gewoont heeft HENRICKJE JACOBS, wed, van JOCHEM CAMPHUYSEN, des requirants moeder, welcke in ' $t$ begin van de maent Julij is overleden 5 ).

Op de tentoonstelling van oude schilderijen, in I 886 te Dusseldorf gehouden, waren twee landschappen, beide gemerkt $\Phi \mathrm{C}$, ingedeeld bij de onbekende Hollanders ( $n^{0}$. I62 en 163 ). Het eene was ingezonden door den heer CARL PaGenstecher te Elbetfeld en vertoonde een rivier met rechts een met boomen beplanten oever, waartusschen eenige daken van huizen zichtbaar waren, en verder op den achtergrond de torens van een kasteel; op de weilanden links

1) Oud-Holland, III p. 73 .

2) Protocol not. F. van Banchem te Amsterdam.

3) Oud-Holland, III p. 73 .

4) Prot. notaris H. Westrisius te Amsterdam,

5 Prot. notaris J. H. LEeUwen te Amsterdam.

Oud-Holland, rgo3. 
graast vee, op den voorgrond zijn twee wandelaars met elkaar in gesprek (h. 40 br. 60, P.). Thans maakt het deel uit van de collectie DaHL te Düsseldorf. Wijlen de heer WERnER DAHL heeft ons in de gelegenheid gesteld er bijgaande afbeelding van te publiceeren. Het andere behoorde den heer NELLES te Keulen. Vóór een boerenhofstede in een bosch staan een man en een vrouw samen te praten, terwijl een jongen een haan onder den arm houdt; rechts over een rivier uitzicht naar een dorp, gedeeltelijk tusschen de boomen verscholen (h. 59 br. 82, p. $)^{1}$ ).

Toen een onzer in de Kunstchronik ${ }^{2}$ ) een landschapje met een geheel gelijk monogram besprak, dat in 1890 op de veiling coll. Dr. WeinHageN te Keulen voor 125 Mark toegewezen werd, sprak hij reeds het vermoeden uit, dat onder die initalen de naam van Jochem CAMPHUYSEN verscholen was, en die meening wordt nog door ons voorgestaan. Ook in de verzameling van wijlen den heer Hugo Toman te Praag waren in I 888 twee ovale landschappen met hetzelfde monogram gemerkt. Op het eene vertoonde zich rechts een kronkelende rivier, en links zware boomen en kreupelhout, waaronder in kleine figuurtjes de boden van Joseph in Benjamin's zak den gouden beker vinden (h. $40 \frac{1}{2}$ br. 30 , P.). Ook de tegenhanger had vermoedelijk een bijbelsche stoffage, waarvan de beteekenis ons evenwel niet duidelijk is; over een brug gaan twee mannen en een vrouw en drijft een herder drie koeien, gevolgd door een ouderen herder met een kudde schapen; op den voorgrond zwemmen eenige eenden, terwijl achter de brug links een groote boom en kreupelhout aangebracht is, waarboven eenige huizen en een kerktoren uitsteken.

Op naam van JAN LooTen bevindt zich in het museum te Bordeaux een landschap dat eveneens met dit monogram gemerkt is. Ook hier een brug over een riviertje met aan beide oevers huizen; rechts wordt ecn landweg door hooge boomen beschaduwd; aardige figuurtjes verlevendigen het fijn gevoelc.elandschap. Het werd in 1829 verworven uit de coll. LACAZE (h. 50 br. 70, P.).

Ook bij den heer Brants te M. Gladbach en in de collectie Glitza te Hamburg bevinden zich twee landschapjes, voorzien van hetzelfde monogram. Het laatste vertoont een weg tusschen huizen en boomen, waarop een in het rood gekleede ruiter (h. 39 br. 49 P.), terwijl op de tentoonstelliug van oude kunst, in 1883 te Berlijn gehouden, door den heer R. STüVE te dier stede een landschap met rotsen ingezonden was met een monogram dat J. G. C. gelezen werd, en aan JACOB GERRITSz. CUYP was toegeschreven. Ons wil het evenwel voorkomen,

1) Dit stukje was njet op de veiling der collectie Nelles, Keulen i6 Dec. I895.

2) Kunstchronik, N. F, II p. I29. 


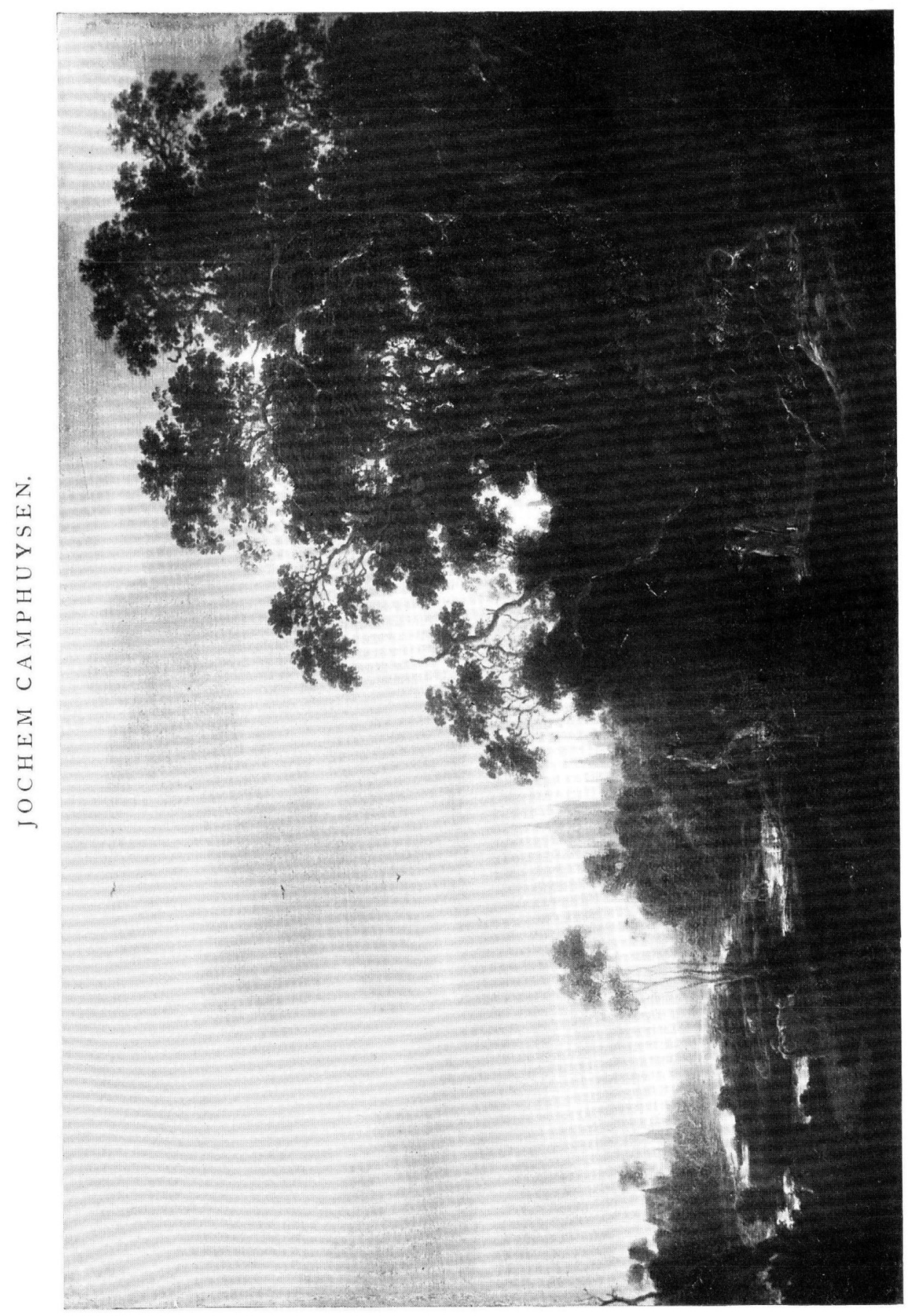

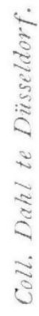



dat die $G$. door de $J$. heen een $O$. is, en Jochem Camphuysen de schilder van het stukje ${ }^{1}$ ).

Waar alleen CAMPHUYSEN bij eenig landschap vermeld is, zonder letter of voornaam, moeten wij twijfelen welke de bedoelde is. Een rotsachtig boschrijk landschap met een waterval, dat in 1843 in de collectie HoLLANDT te Brunswijk was (h. I' $6^{\prime \prime}$ br. 2', D.) wordt door PARTHEY ${ }^{2}$ ) voluit gemerkt genoemd, waar toch natuurlijk bij DrRCK opgeborgen. Wij hebben het stuk niet terug kunnen vinden, maar de korte beschrijving doet meer aan de weinige stukken van Jochem dan aan die van RAFEL denken.

Geheel geen oordeel kunnen wij hebben over mededeelingen uit oude inventarissen, want slechts zeer zelden werd hierbij de voornaam genoemd. Alleen werden op de verkooping van de verzameling van BoUdewyn DE MAN te Delft in I644 "twee lantschappen van JoACHIM CAMPHUYSEN" voor $f 7$. - verkocht, en bezat in 1674 Dr. PISO te Amsterdam „een boereschuyr van JoACHim CAMp. HUYSEN".

De landschappen van dezen meester dragen meest een nog wat ouderwetscher karakter, dan die van zijn broeder RAFEL. Sommige hebben overeenkomst met de vroegste werken van AERT VAN DER NEER. Zijn bosschen en geboomten neigen naar het zwarte; het gebladerte is zeer fijn uitgevoerd en zijne stoffage ook minutieus gepenseeld. Toch spreekt er een ernstig gevoel voor het schoone van het landschap, meestal bij avondschernering, uit zijn schilderijen. Laten wij hopen, dat één werk van dezen schaarschen meester nog cens het eigendom worde van een onzer publieke verzamelingen!

\section{GOVERT DIRCKSZ. CAMPHUYSEN.}

Boven hebben wij gezien dat ook Dirck Rafelz. Camphuysen, de oom van de beide pas behandelde landschapschilders aanvankelijk voor schilder was opgeleid, maar dat hij omstreeks I604 de beeldende kunst vaarwel zei, om zich aan de studie te wijden. Voor zijn veelbewogen leven verwijzen wij naar de het onderwerp geheel uitputtende monographie van L. A. RADEMAKER ${ }^{3}$ ) en brengen slechts in herinnering, dat hij I I April I6I3 te Dordrecht in het huwelijk trad met ANNa VAN ALENDORp Govertsdr. Zijn schoonbroeder Johanes van AleNDQRP bezorgde hem spoedig daarua een bestaan te Gorinchem, waar zijn oudste zoon geboren werd, WERNER, genoemd naar den vader van Mevrouw VAN BOETSE-

1) Jahrbuch der $\mathrm{Kgl}$, preussischen Kunstsammlungen, IV p. 203, zo4.

2) G. PARthex, Deutscher Bildersaal, I, Berlin r863 p. 240.

8) L. A. Rademaker, Didericus Camphuysen, Gouda 1898. 
LAER, die het kind ten doop hield. Kort daarna kreeg hij een betrekking aan de Hieronymusschool te Utrecht. Hier werden geboren zijn dochter ELISABETH, genoemd naar de freule VAN BOETSELAER en zijn zoon RAFEL, genoemd naar zijn vader. Het gebruik bracht mede, dat een volgende zoon naar moeders vader genoemd werd, en daarom was GovERT vermoedelijk de daarna geboren zoon. GoverT zelf gaf in 1647 op, dat hij toen 23 jaar oud en te Gorinchem geboren was. Toch is dit laatste denkelijk niet juist, want de ouders woonden daar toen niet. I7 Mei 1617 was de vader benoemd tot predikant te Vleuten, welke plaats hij echter reeds in I6I9 door de bekende beroeringen in de kerk moest verlaten. Sedert begon voor hem een zwervend leven. Verbannen uit de Vereenigde Provintiën begaf hij zich aanvankelijk naar Waalwijk. Hier schonk omstreeks November I6I9 zijn vrouw hem weer een kind, maar wij weten niet, of dit in het leven bleef. Bedektelijk vertoefden CAMPHUYSEN en zijn vrouw daarna eenigen tijd te Amsterdam, om in het voorjaar van 1620 een veilige schuilplaats te Norden in Oost-Friesland te vinden. Maar reeds in Oct. 1622 begon het reizen en trekken opnieuw. Eerst bood Harlingen en na een jaar Ameland een veilig verblijf, tot hij in het einde van 1623 of in het begin van 1624 te Dokkum en nu voor goed een schuilplaats vond. Is de leeftijdsopgave, door GovER'T in 1646 gegeven, juist, dan zal hij vermoedelijk te Harlingen, op Ameland of te Dokkum geboren zijn, en bedoelde hij met Gorinchem als geboorteplaats slechts, dat zijn familie daar eigenlijk thuis behoorde.

9 Juli 1627 brak voor DiRCK RAfelsz. CAMPHUYSen eindelijk het uur der verlossing aan en stierf hij. Op de ontwikkeling van zijn zoon GOVERT heeft hij dus geen invloed meer kunnen uitoefenen. Zijn aanleg voor de beeldende kunsten had trouwens niet belet, dat zijn sympathie ervoor geheel was verdwenen, zoodat hij zelfs een philippica schreef „Tegen 't Geestig-Dom der Schilderlionst, straf-rymen of anders Idolenchus, uyt het Latyn vertaald", ") waarin hij hevig uitvoer tegen de schilderkunst.

De weduwe bleef aanvankelijk te Dokkum. Later trok zij naar Amsterdam ${ }^{2}$ ), wanneer is niet bekend, maar stellig vóór 1643 , en wij hebben dus geen gegevens, waar GOVERT zijn kinder- en jongelingsjaren heeft doorgebracht.

I I Sept. I643 verklaren te Amsterdam eenige personen, waarbij de vrouw van

1) Stichtelycke Rymen, Haerlem 1645 p. 399.

2) $Z_{\mathrm{ij}}$ stierf eerst te Amsterdam in 1668. Haar besrafenisbriefje berust in de Bibliotheek van het Friesch Genootschap te Leeuwarden: „Anno I668, tegens Dinghsdagh, den 4. September, werd U. E. ter Begraffenisse gebeden, met ANya van Aldendorp, weduw' wylen Diderick Camphuysrn, in zijn leven Remonstrants Predicant, moeder van Raphael Camphuysen, en Godefridus Campiluysen. Voor-aen op de Linde-graft in 't Wapen van Vlaerdingen, aen de Noortzy. Ten een uur als Vriendt in Huys te komen om voor twee uuren precijs te sijn in de Noorder Kerck'. 
Johannes Van VRatum 1), hoe waar is "dat Annetje Camphuysen, moeder van Govert Camphuysen, Schilder, tot diversche en verscheyde malen heeft geseijt, dat de gemelte Govert CAMPHUijSEN, haer soon, de dochter van de requirant [TRIJNTGE BITTERS, huijsvrouw van JAN BITTER, cleermaker], hadde geconterfeyt ende geschildert, welck conterfeijtsel sij ende van gelycken haer soon, de requirant geschoncken ende vereert hadden; ende dat de gemelde GoverT CAMPrutusen tot diversche reijse tegens haer getuyge heeft gesegt, dat hy des requirants dochter, genaemt GRIETJE BITTERS hadde geconterfeijt, en dat hij haer hetselve conterfeytsel hadde geschoncken voor groote dienst en vrientschap die hy ende sijne moeder ten huijse van de requirant genoten hadde" s).

9 Febr. I647 is de ondertrouw aangeteekend van "Govert Camphuysen, van Gorkum, schilder, out 23 jaer, wonende op de Lindengracht, noch een moeder hebbende, geassisteert met syn broeder Raphel Camphuysen ${ }^{3}$ ), en Nelletje FRANCKEN ${ }^{4}$ ), van Amsterdam, out 20 jaer, wonende op de Roosegracht, geassisteert met ANTHon Francken, haer vaeder" s.

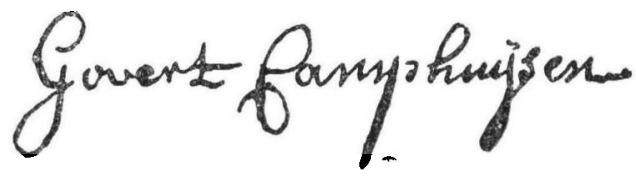

Een eerste kind uit dit huwelijk, dat 24 Febr. voltrokken werd, is zeer jong ten grave gedragen: „22 Juni 1648 , in de Nieuwe Kerk. Een kind van Govert CAMphuysen in de Roosestraet". 24 April I650 werd zijn dochter LySBETH gedoopt.

Toen hij nog bij zijn moeder op de Lindegracht woonde, dus achter de Noorderkerk, schreef Johannes MolinaEus hem een brief, waarin deze den voornaam $\mathrm{N}$. invulde. Dit bracht RADEMAKER in den waan, dat er nog een zoon van den dichter geweest is, wiens voornaam met een $\mathrm{N}$. begon, doch dit

1) Dezelfde "plaetsnijder en mutsedrucker", omtrent wien een jaar te voren RAFEL Govertsz. CampHUYSEN een gunstig getuigenis had afgelegd.

2) Prot. not. J. DE GRaEFr te Amsterdam.

3) Deze Raphel Camphuysen zou volgens een notitie op het begrafenisbriefje van zijn moecler, in het Friesch Genootschap te Leenwarden, waarop al dc kinderen geschreven waren, ook schilder geweest zijn. Dit is niet geheel juist, want er is slechts een afschrift van zulk een opgave, en deze copie gaat blijkens het schrift niet verder terug dan tot het midden der achttiende eeuw. Maar wat erger is, het medegcdeelde verdient geenszins vertrouwen; ook het sterfjaar van den vader is 1626 , dus één jaar te vroeg opgegeven. Er staat overigens over dezen RAPHEL: „RAPHEL KAMPHUYSEN. Volgens begravenis Briefje Op't kathuysers Kerkhot I69I den 6 Juni, geweest schilder".

4) Haar moeder Anna van Glabbeeck was verwant aan Johanna van Glabbereck, de vrouw van den schilder WILLEM ORMEA te Utrecht.

5) Oud-Holland III, p. 73. 
is niet juist. De brief bevindt zich in het archief der Remonstrantsche gemeente te Rotterdam en luidt :

Aan N. Kamphuysen.

Schilder woonende achter de Noorder Kerk.

Tot Amsterdam.

Waarde Vriend en Broeder in Christo.

Hier nevens gaan de printen, tekeningen en schetzen, daar ik UEe in de voorlede week van gesproken hebbe. UEe kuntze eens doorzien, en dan overwegen wat $U E$ e raadzaam oordeelt om der mede te doen. Mijn advijs zoude zijn, dat UEe eens zien zoude, of ze op de verkopinge van Schilderijen van Everding aan de man konden raken, te weten als de schilderyen opgeveilt en verkogt zijn. Dat zoude de vrienden of erfgenamen van de voorn. Everding kunnen verzogt worden, dic er mogelijk niet tegens zouden hebben; ten ware mogelijk dat ze zelve na de schilderijen zulk goed wilden verkopen, en dan zoude het misschien ook niet raadzaam zijn. Ik heb dikwils gezien, toen ik tot Leiden studeerde, dat er een deel boeken op aucties verkogt werden die in de Catalogus niet en stonden; en zo zoude ik meenen dat men ook dit goed in zoo een verkopinge van schilderijen zoude kunnen aan de man helpen: Want mogelijk zijn ze van zulken waardij niet, dat men der een verkopinge apart om aanstellen zoude. Dog ik beveel alles $U_{W}$ oordeel en voorzichticheit, als dewelke hier veel beter kennisse af heeft als ik, en zal mij zelve ook genoegen en volkomen te vreden stellen, in 't geen $U E$ e daar mede zal doen. Immers dit verzoek ik, dat UEe dit goed aan de man gelieft te helpen, 't zij dan wat er af komen mag; ten ware alleen dat UEe bedenken had dat er niet bijzonders af komen zoude, en dat het geen moeijte nog eenige onkosten waardig was. Ik zal dan eerstdaags door een briefje UEe advijs en oordeel afwagten, en van de somer ook UEe zelve eens, verzekerende $\mathrm{UE}^{\mathrm{e}}$ dat gij mij van herten welkom en aangenaam zult zijn, ja dat ik mij gelukkig zal agten bezogt te worden van een soon, die ik beminne om sijn eerwaardige en godzalige vader, wiens schriften bij mij in zeer groote waarde zijn. Zijt voorts met $U_{w e}$ Suster ${ }^{1}$ ) Gode en zijne genadige bescherminge van herten bevolen, van UEe zeer genege

Vriend en Broeder J. Molinafus.

1) Deze zuster, Maria, is eerst in I700 te Amsterdam gestorven. Haar begraf $:$ nisbriefje, ook in de bibliothcek van het Friesch Genootschap te Leeuwarden luidt: „Anno I7oo. Tegens Saturdag den 3 de April, werd UE. ter Begraavenis verzocht, met MARIA CAMPHUYzen, bejaarde dochter van wylen DirCk RAphazlsz. Camphuysen. In de Bo omstraat, verby de I) warsstraat: als Vriend in huys te komen, om ten half drie uuren te gaan naa 't Kathuysers Kerkhof. UE. Naam zal gelezen werden". Ook is te harer gedashtenis een penning vervaardigd waarop haar geboorte te Vleuten I Mei I6I8 en haar overlijden te Amsterdam 29 Maart 1700 is aangegeven. 
In een overigens onbelangrijke acte van 27 Oct. 1648 , handelende over een onbeschaamde dienstmaagd, die zich tegenover CAMPHUYSEN en die ${ }_{\iota}$ S vrouw onbehoorlijk gedragen had, leeren wij twee leerlingen van hem kennen: "REGARDUS DE Groot, oudt omtrent 18 jaeren en JaN Pietersz. Opperdoes ${ }^{1}$ ), oudt omtrent I6 jaeren, beyde discipelen en leerlingen in de teeckenconst, PiETER SwarT ${ }^{2}$ ), constschilder, out omtrent 2 I jaeren, dewelcke ter requisitie en versoecken van Sr. Govert van CAMphuysen, constschilder, verclaert hebben,.... eerst de twee eerste getuygen, dat zyluyden woonende ten huyse van den producent, gesien hebben", enz. ${ }^{3}$ )

Ofschoon „Govert Camphuysen van Gorcom” zich 16 Maart i650 nog als poorter van Amsterdam had laten inschrijven ${ }^{4}$ ), kreeg hij reeds spoedig daarna reisplannen, zoo hij niet al om schulden weggereisd was. Vermoedelijk in verband daarmede is 4 Maart 1652 een inventaris opgemaakt "van de meubelen ende huijsraet, bevonden in den boedel van Goivaert Camphuijsen. Heef gewoont in de Calverstraet by de Doelen.

\section{In 't voorhuijs:}

Een groot schildery, sijnde een lantschap met eenige beelden. een conterfeytsel sijnde een fluijter. een schilderijtge synde een belblaesertje. 4 spaense stoelen, met roode fulpe sitsels. een half casje. 3 pleysterde beeltjens. een ossenhooft van pleijster.

2 gedrayde stoelen. een schilderesel. een sitsoldertje. een stuck goutleer.

\section{In de binnencamer.}

7 matte stoelen.

I eecke taeffeltje.

I geschildert cannebort.

I dito tresoortje.

I braet spit.

I prentbortje.

eenige rommelingh.

1) Op de verkooping coll. graaf RASPONi te Amsterdam werd in $188_{3}$ een aan EMANueL Murant toegeschreven schilderij gekocht voor het Rijksmuseum te Amsterdam, voorstellende een hofstede, dat gemerkt bleek te zijn: OpPeRuoes.

2) Van bem is een landschap bij den heer Hibde NijLaxd te Dordreciat.

3) Prot, not. Fr. Meernout te Amsterdam.

4) Di. P. Scheltema, Rembrandt, Arnsterdam I853 p. 70. 


\section{Op de achtercamer.}

Twee ossehooffden van pleijster. een dito hont. een oude coffer, 2 doeckjes, I beugelstoel, I eesel, 2 lijsten.

\section{Op de solder.}

I vrijffsteen en eenige rommelingh. ${ }^{\text {) }}$

Hij trok naar $Z$ weden en heeft zich daar de gunst van het hof weten te verwerven. Tenminste in Mei en Nov, I655 is te zijnen behoeve een uitbetaling geboekt op de civiele lijst van koningin HEDwig Eleonora ${ }^{2}$ ). Het eenige schilderij, dat wij in $Z$ weedsch koninklijk bezit hebben aangetroffen is een „Brun hund" op het slot te Gripsholm (h. 4.80 br. 5.90), dat volgens den catalogus der daar aanwezige schilderijen gemerkt zou zijn: G. CAMPHUISEN 156r, wat wel een drukfout voor $165 \mathrm{I}$ zal wezen. Graaf C. G. Tessin vertelt in zijn Tessin och Tessiniana, dat hij portretten en andere schilderijen gezien heeft, gemerkt "CAMPhuysen. Holmiae" ${ }^{3}$ ). Een dergelijk stuk was in I87 I bij zekeren T. S. A. op Lindoxe Abbey te Newburgh-on-Tay. Toen schreef de bezitter een vraag in de Notes \& Queries ${ }^{4}$ ) "I have an old painting signed on a painted tablet (part of the picture) ",G. CAMphausen, Stockholm"'. When did he live? Was he noted?" Ook FuessLI noemt een portretschilder Camphuysen, die vermoedelijk in $Z$ weden werkte en waarnaar PADTBRUGGE gegraveerd heeft. ${ }^{5}$ ) Ons is alleen bekend het portret van OLOF LARSSON, gegraveerd door D. PADTBrugGe, waarop staat "G. CAMPHUySEN pinx".

7 Aug. 1659 was hij [Gothried Camphusen] doopgetuige in de St. Gertrudiskerk te Stockholm, 12 Juni I66 I wederom [Gotfrid Campenhusen], 2 I Mei I663 „Mons. Camphusens fraw” en I9 Oct. $166_{3}$ nog eens "Conterfeyter Camphusens traw" 6).

De geldzorgen, die hem vermoedelijk naar Zweden gedreven hadden, verlieten hem ook daar niet. In een lange acte van $26 \mathrm{Juli}$ r66 I laat de familie van zijn vrouw den notaris J. PONDT een vordering op CAMPHUYSEN in een brief naar Stockholm zenden, waaruit bleek, dat hij 28 Febr. I65 I bekend had „schuldig te wesen aen myn schoonvader ANTHONY FRANCKEN de somme van

1) Desolate Boedelkamer.

2) O. Grankerg, Les collections privées de la Suède, Stockholm i886 p. I03.

3) O. GranberG, u. 5. p. IO4.

4) Notes \& Queries, $4^{\text {th }}$ series, VII, London I87I p. 188.

5) H. H. Fuessli, Allgemeines Künstlerlexikon, II, I p. 806.

6) O. Granberg, u. s. p. Io3. 
$f$ 315.- die ick beloove te betalen over I 2 maanden", welke terugbetaling niet geschied was. ')

Wanneer hij teruggekeerd is, weten wij niet, maar in Mei 1665 woonde hij zeker weer te Amsterdam. 22 Juni i667 verklaart „d'Eers. Govert CAMPHUySEN, van competenten ouderdom", dat zijne huisvrouw en hij van Mei I665 tot Mei I667 twee kamers aan iemand verhuurd hadden in het huis in de Dijkstraat van JACOB CRETEAU, waaruit hij dept. onlangs vertrokken was ${ }^{2}$ ).

Die "competente" ouderdom heeft er hem zeker toe gebracht, aan zijn testament te denken. 20 Juni $\mathrm{I} 667$ is dat van „Sr. Govert Camphuysen en Joffr. Petronella Francken, echteluyden, wonende binnen deser stadt" gepasseerd voor den notaris Cornelis Touw. Er was één kind, Elisabeth. De Weeskamer werd uitgesloten.

Nog eenige geldquesties van weinig belang worden aangeroerd in de beide actes, die ons verder over den schilder bekend werden. I5 Dec. I667 verkoopt hij met JAN DE KOKER aan WARNAR VAN BRONCKHORST het zesde gedeelte van een huis aan het Damrak, waar de Roode Molen uithangt, voor $f$ 3200.-, en in Nov. i668 komt Godefridus Camphuijsen, als getrouwd hebbende Petronella Francken ,kinderen en kintskinderen van Franck Janssen haerl. vader en grootvader", voor in een zaak over de erfenis van een nicht MARIA Duyvens, de gewezen huysvrouw van Hendrick van Twenhuysen ${ }^{3}$ ).

4 Juli 1672 werd in de Nieuwe kerk begraven „Godefridus Camphuysen, op de Oude Schans"...f 8.- ${ }^{4}$ ) Zijn weduwe volgde eerst veertien jaar later: „Anno I686. Tegens Vrydag, den 13. December, werd UE. ter Begravenis verzogt, met Petronella Franken, Weduwe van wijlen Godefredus Camphuysen. Buyten de Leydse-poort, alwaer een Schuyt gereet sal leggen de klok tien uren, om precijs te zijn ten een uur t'Amsterveen in de Kerk. UE. Naam sal gelesen worden".")

Met zijn werk is het al even zonderling gegaan als met dat van zijn neven RAFEL en JOCHEM. Meestal zwierf het onder vreemde vlag de wereld rond. Helaas heeft hij het slechts zelden noodig gevonden eenig werk van een jaartal te voorzien. Wij kennen er slechts twee. G. CAMPIUUJSEN I645 is een schilderij gemerkt, dat in 1880 als het eigendom van den heer L. C. THEOdorE H. GaLtoN tentoongesteld was in Bethnal Green Museum te Londen. In een stal waar vier koeien staan, is een meid bezig een emmer te schrobben. En

1) Prot. not. J. Pondr te Amsterdam.

2) Prot. not. H. Rosa te Amsterdam.

3) Prot. not. G. Steeman te Amsterdam.

4) Oud. Holland III p. 73 .

5) Begrafenisbriefje in de Bibliotheek van het Friesch Genootschap te Leeuwarden.

Oud-Holland, 1903 . 
G. Camphuysen i650 staat op een der fraaiste van zijne werken, in het museum te Brussel. In een stal, waar links een tweetal koeien van achteren gezien zijn, de eene staand, de andere liggend, zit voor het venster een boerenmeid voor een tafel, waarop een tobbe en een kool; lachend wendt zij zich met de opgeheven linkerhand om naar een man, die haar onverhoeds beet pakt, waar rechts om den hoek van een deur een andere man naar kijkt. Het stuk was in 1873 op de tentoonstelling van oude kunst te Weenen ingezonden als een JochEM CAMphuysen, en werd op de verk. der collectie von Lissingen (Weenen), Parijs I6 Maart 1876 voor 6720 frs, voor het museum te Brussel gekocht. W. UNGER maakte er een onbeduidend etsje naar voor den catalogus der veiling voN LISSINGEN (h. 69 br. 55 , P.).

Dat motief van een boerenmeid, die door een man gepakt wordt, was CAMPhuysen bijzonder welgevallig. Herhaaldelijk toch heeft hij het te pas gebracht, o. a. op een schilderijtje van kleiner afmetingen in het Rijksmuseum te Amsterdam. Hier houdt de meid zich om niet achterover te vallen aan een poot van de tafel vast. De omgeving is iets anders gecomponeerd. Rechts is een klein raampje, waarvoor de tafel met een bord en een groote kool; achteraan staan rechts twee koeien, nu van voren gezien, en links op den voorgrond staat een ton en een omgeworpen mand. De naamteekening op een plank in het midden vooraan is vervalscht in die van PAUlus PotTer, maar G. CA.... van de echte namteekening is nog te onderscheiden. Het stukje is in 1892 door Mevr. Messchert van Vollenhoven-van Lennep aan de stad Amsterdam gelegateerd en was in 1867 op de tentoonstelling te Amsterdam ingezonden door den heer W. P. VAN LENNEP. De beschrijving van een dergelijk stukje in de verkooping der collectie J. VAN DER MARCK (Leiden), Amsterdam 25 Aug. 1773 , komt zoo volkomen ermede overeen, dat het aan geen twijfel onderhevig is, of het is hetzelfde stukje. Toen werd het voor $f 167$ toegewezen aan zekeren MAARSEVEeN (h. $32 \frac{1}{2}$ br. $35 \frac{1}{2}, \mathrm{P}$ ).

Een bijzonder mooi specimen bezit ook de heer von CARSTANJen te Berlijn. Hier zit de meid rapen schoon te maken, terwijl ze zich verweert tegen de omarming van een jongen boer; aan den kant wederom twee koeien, de eene staand, de andere liggend; op den achtergrond een tweede meid, die een pot over het vuur hangt; het door de geopende deur binnenvallende zonlicht vult het vertrek met een warmen toon. Het is gemerkt: G. CAMPHuIjSEN en werd aangetroffen op een reeks van veilingen van vermaarde kabinetten: Coll. GERRIT VAN DLR PaLS, Rotterdam 30 Aug. I 824; coll. RHaban RuhL, Keulen I 5 Mei I 876 (4500 Mark); coll. NeLles \& Henckels, Keulen I6 Dec. r895 (3400 Mark). Met bijzonderen lof is het vermeld door BuRGER ${ }^{1}$ ) (h. 64 br. 55 , P.)

1) W. Burger, Musées de la IIollande, II, Bruxelles I860, p. $24^{2}$. 
In de Hermitage te St. Petersburg zijn er zelfs twee. Op het eene verweert de meid zich lachend tegen een jongen dic naast haar zit en haar bij de rokken pakt; op den grond liggen verschillende huishoudelijke artikelen en smeulen eenige kolen onder de as; links kijkt, met de vinger dreigend, een oud man door het venster, waarnaast aan ecn balk een kip hangt; rechts staan langs de muur zes koeien; op den achtergrond gaat een vrouw naar een schuur vol tobben en dergelijk gerei. Het stuk is afkomstig uit de collectie BRüHL te Dresden, I769. Met de naamteekening heeft men weer geknoeid en er PoTTEk van willen maken, maar de $G$ en de $C$ en eenige andere letters van de echte signatuur zijn nog te zien (h. I.47 br. 60\%, P.).

Op het andere zit de meid zich lachend met handen en voeten te verdedigen, zoodat een mand met groente, waarnaast twee aarden potten en een emmer op een ton staan, is omgevallen; links achteraan twee koeien, waarboven de hooizolder, dien men bereikt door een trap naasthet geopende venster; boven op dezen trap kijken een man en een vrouw naar wat er beneden voorvalt; rechts op den achtergrond zit een poes bij het haardvuur. Het stuk is verworven onder keizerin Cathakina II, en gemerkt: G. CAmphuysen (h. $62^{7} / 10$ br. $52^{2} / 10, P$ ). Een geheel gelijke herhaling hiervan schijnt de schilderij geweest te zijn, die te Parijs in 1804 op de veiling der collectie VAN LEVDEN voor 4750 frs. toegewezen werd aan DeLARoche. In $18 \mathrm{I} 4$ was het weer op de verkooping PAILLET te Parijs, maar bracht toen slechts I030 frs. op. ${ }^{1}$ ) Een teekening hiernaar door Abraham Delfos was op de verk. Amsterdam 23 Juni I885, no. 353.

Ook Jhr. Mr. K. A. Govin DE BEAUforT te Utrecht bezit een stuk van hem met een dergelijke voorstelling. Op een boerenerf wordt een melkmeid door een jongen omhelsd, waar de over de onderdeur der boerderij leunende boer en boerin naar kijken; rechts op den achtergrond een dorpsgezicht. In I 894 ingezonden op de tentoonstelling te Utrecht (h. 42 br. 63, P.).

Dat motief van dien stoeienden boer en boerin bracht hij ook aan op een grootere compositie, die bijna meer dan een eeuw lang als een meesterwerk van POTTER bewonderd is in de Keurvorstelijke Galerij te Kassel. Vóór eenig struikgewas rechts op den voorgrond ligt een zwart wit gevlel-te koe en een schaap, er achter staat een rood wit gevlekte koe en links een lam. Rechts wil een jonge lachende boerenmeid met een juk met twee emmers op de schouders door een hekje het vee naderen, maar ze wordt vastgehouden door een eveneens lachenden jongen; links voert een weg door het bosch en opent den blik op een vergezicht. Deze kapitale schilderij (h. 204 br. 275 , D.) werd in 175 I door 
MOREL voor den landgraaf uit Engeland verworven als een POTTER, wiens naam er dan ook zeer duidelijk op stond: Paulus Potter r65I. John Smith was de eerste die twijfelde aangaande PotTers aandeel, maar toch werd nog in het bekende Kasselsche galerijwerk een ets van UNGER opgenomen, die het aan hem toeschreef. Toen echter later A. HAUSER JR, de echtheid der naamteekening aan een onderzoek onderwierp, verdween deze reeds bij de eerste proefneming. En thans twijfelt niemand meer aan CAMphuysen als de schilder van dit stuk, dat van 1806 tot 1815 te Parijs was.

Maar om tot de binnenhuizen terug te keeren. Hij stofteerde deze ook wel op andere wijze. Zoo vertoont een stuk in het museum te Breslau een slecht verlicht boerenvertrek warin een oude vrouw met een poes op schoot bij een van de zoldering af hangende ketel voor het vuur zit; om haar heen een ton waarop een kruik, ketels, kruiken enz. en links een groote karnton, waarachtet verscinillende koeien door een beschot kijken; rechts is bij een klein venster een man achter een bed bezig; nog ziet men op den achtergrond door een geopende deur in een nevenvertrek gevuld met allerlei gereedschap. Dit vrii zwakke en wat de figuren betreft ook zeer bedorven werk komt uit de coll. BACH, in I 829 te Breslau overleden, en is gemerkt: G. CAMphuvsen (h. 47 br. 63, P.).

De heer A. M. A. Smits te Amsterdam bezit een boerenbinnenhuis met twee figuren, dat in 1867 door den heer HAFKENSCHEID ingezonden is op de tentoonstelling van oude kunst te Amsterdam (h. $3^{8 \frac{1}{2}}$ br. 47).

In het museum te Kopenhagen een in $\mathbf{I} 744$ gekocht klein schilderijtje, dat heel wat verwarring aangericht heeft, omdat men uit de verkeerd gelezen voorletters een nieuwen P. T. CAMPhuYsen gefabriceerd heeft. Terwijl de boer bezig is de koeien te verzorgen wiegt de vrouw het huilende kind (h. I 8 br. 24, D.).

Van schilderijen op verkoopingen voorkomende vermelden wij een binnenvertrek met een man en vrouw bij het vuur zittend; op den voorgrond staat bij een venster een tafel met huisraad, groente enz. waarnaast op den grond eenige koperen ketels en dergelijk gerei. Verk, coll. Douair. van Tuyll van Serooskerken geb. Barones DE PAGNiet, Utrecht 26 Juli I 836 (h. 4 p. 6 d., br. 6 p. I d. P.)

Een boerendeel met allerlei gereedschap. Verk. coll. Rochart, Brussel I 858 .

Een vrouw, bezig met het schoonmaken van visch, is in gesprek met een man die over de onderdeur hangt. Verk. coll. SaRphati, Amsterdam 7 Nov. I 866 (h. $4 \mathrm{I}$ br. 49, P.).

Een rapenschillende vrouw in een kamer waar schilderijen aan de muur hangen en een clavecimbel staat. Verk. Amsterdam 7 Mei 1895 en 24 Nov. 1896 (h. 50 br. 65, P.). Afgebeeld in den catologus van 1896.

Van zijn tafereelen in de open lucht hebben wij het groote stuk te Kassel, 



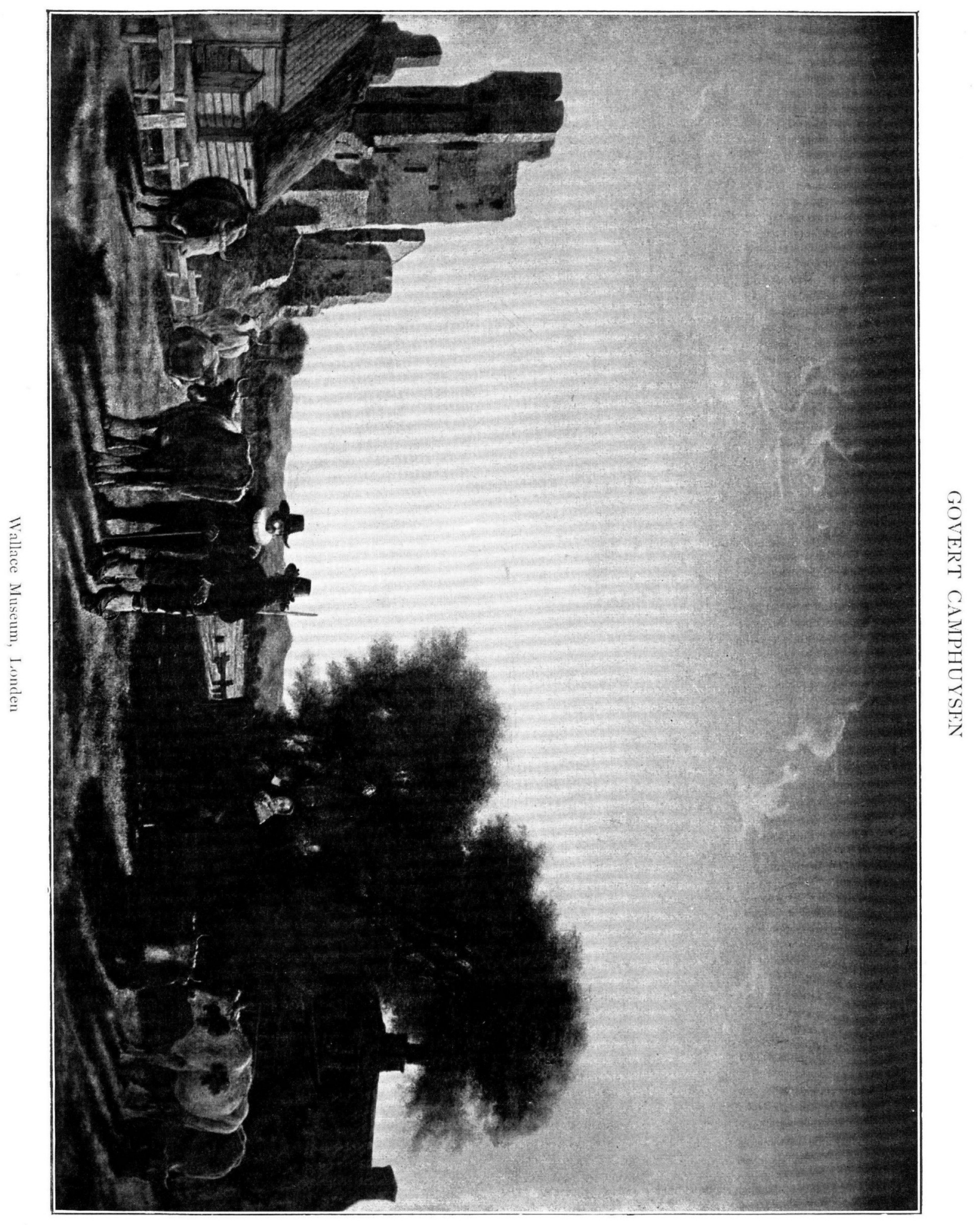





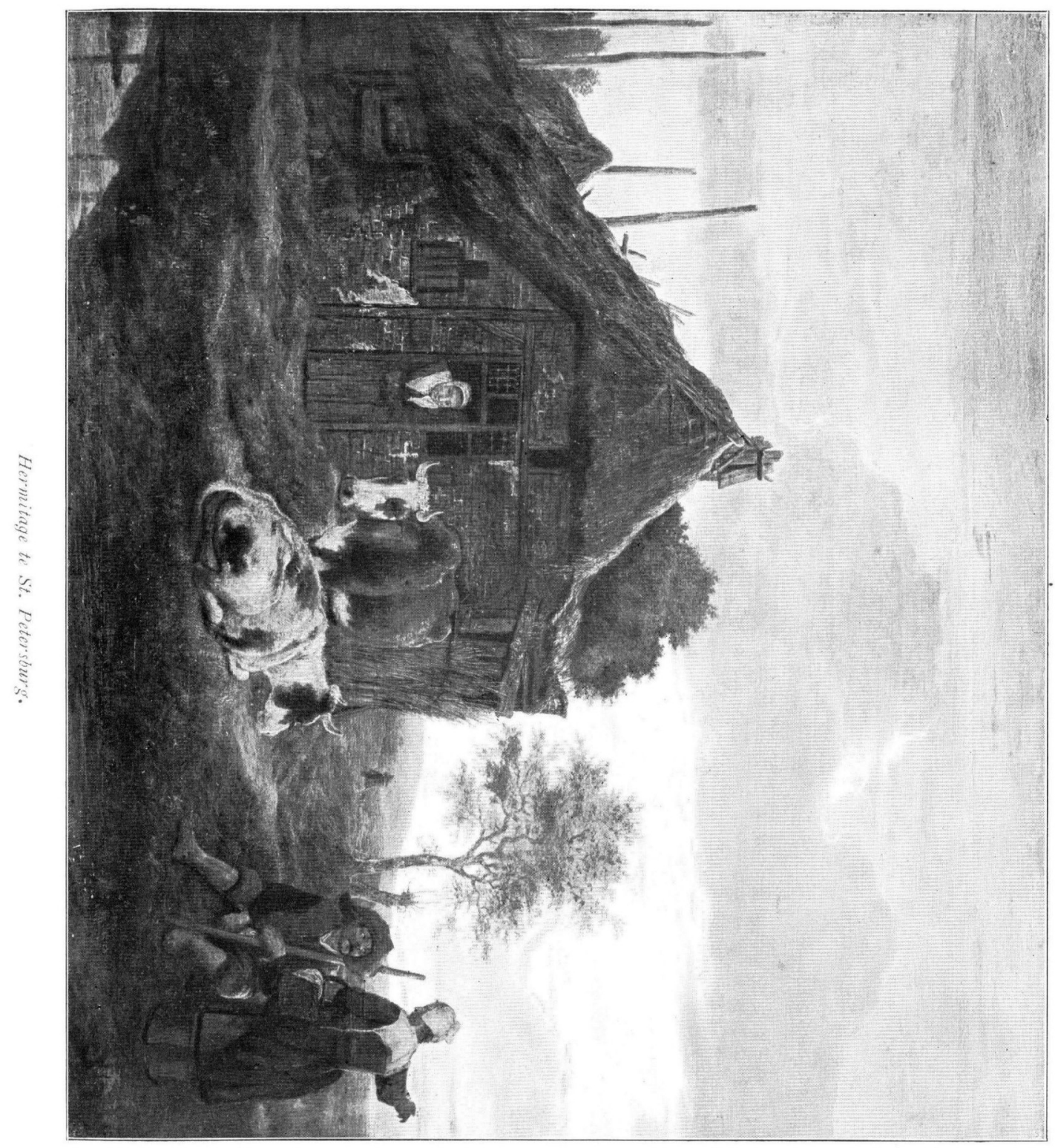

0
0
5
0
0
4
2
2
3
0
4
6
0
0
3 
waarin hij kennelijk den Stier van Potter trachtte na te volgen, reeds genoemd. Er zijn er nog vele, en ofschoon hij hier minder gelegenheid had om zijn groot gevoel voor het invallend licht in een vertrek te laten spreken, zijn er stukken bij van meer dan gewone verdienste.

In de Hermitage te St. Petersburg het hiernevens afgebeelde stuk: Vóór een boerenhuisje bevinden zich twee koeien, de eene liggend, de andere staand, die gadegeslagen worden door de over haar onderdeur hangende boerin. Rechts op den voorgrond zit een herder met een stok over zijn schouder en spreekt tegen een vrouw die met wijzend gebaar den rechterarm uitstrekt. Op den achtergrond een heuvelachtig verschiet. Het stuk is verworven onder CATHARINA II en draagt de valsche handteekening: Paulus PotTer f. 1658 (h. $53^{6} / 10$, br. $6 \mathrm{I}^{1} / 10$, P.).

Dulwich Gallery: Vóór een boerenhuisje graast eenig vee. Op den voorgrond staat een herder, blootsvoets, met zijn schoenen aan zijn gordel hangend; hij steunt met zijn rechterhand op een stok en steekt de linkerhand uit; naast hem staat een boer; rechts nog eenige boerenhuisjes en een wagen met koren, getrokken door twee paarden. Uit de coll. Noel Jos. Desenfans, die het gekocht had voor den in 1798 overleden STANislaus Poniatowski te Warschau. Na den dood van DesenFans in $1807 \mathrm{kwam}$ het aan Sir Peter Francis BoURGeois, die het aan Dulwich College legateerde. Ook al valsch gemerkt: PaUlus PotTER.

Het fraaiste stuk in dit genre bevindt zich in het Wallace-Museum te Londen. Op een weiland, links begrensd door de bouwvallen van een kasteel, waarin wij het huis te Cleef bij Haarlem meenen te herkennen, rechts door een onder boomen half verscholen boerderij, staat een herder te praten met een heer; rechts komt een paar, eveneens uit den deftigen stand, van de boerderij af. Een aantal koeien zijn over den voorgrond verspreid. In het verschiet ziet men over de weilanden heen naar de duinen. De ondergaande zon teekent de omtrekken der beide mansfiguren op den voorgrond scherp tegen de roode lucht, en werpt zware schaduwen over het weiland. Dit uitnemende werk, waarvan een afbeelding hiernevens gaat, werd op de verkooping der collectie van Lord NoRTHWICK (Thirlestane House) in I 859 voor \& 5 lo gekocht door den Markies van HERTFORD.

Vermoedelijk uit zijn $Z$ weedschen tijd is een landschap in Zweedsch karakter, met rechts op den voorgrond een riviertje, links op den tweeden grond een groepje boomen waarvóór een hooge dikke berk staat. Rechts geleiden een herder en een herderin een kudde, waarvan een stier door een hond aangeblaft wordt, en verheft zich op den achtergrond een kerk. Gemerkt G. KampHuIS... $\mathrm{Bij}$ den koning van $\mathrm{Zweden}$, en afkomstig uit de collectie van koningin JosEPHINE (h. 71 br. 74 , D.).

Een motief, dat hij ook gaarne te pas bracht, was een wagen met feest- 
vierenden vóór een herberg. Vooral bekend is dat in het museum Boymans te Rotterdam. Drie boeren en boerinnen zitten in feestelijke stemming in den wagen en worden aangesproken door een bedelaar, terwijl de waardin vóór de huisdeur staat en de koetsier roggebrood voor het paard snijdt. Het stuk staat reeds op den inventaris die in $\mathrm{I} 8 \mathrm{II}$ van de collectie Boymans opgemaakt is, en is gemerkt: G. CAmphuysen (h. 57 br. 65 , D.). Als het ware een pendant hiervan is bij den heer JoHN G. JoHnson te Philadelphia. Hier reikt de waardin een glas bier aan een passeerenden ruiter en geeft een staljongen de twee paarden te drinken, die voor den wagen met feestvierenden zijn gespannen.

Een andere halte vóór een herberg werd in 1895 te Berlijn aangekocht voor het museum te Praag (h. 48 br. 66, P.). En ook op het landschap in de coll. DAHL te Düsseldorf, waar een dorp half onder de boomen verscholen aan het. water ligt, rijdt een wagen vol feestvierenden weg van een herberg. Het stuk was op de tentoonstelling te Düsseldorf in I 886 en is gemerkt: . CAMPHUYS. . (h. 47 br. 63 , P.)

Ook op verkoopingen troffen wij er aan. Verk. coll. Schönborn, Amsterdam I6 April 1738: „Een Plyster-Plaats" ( $f$ 36.10). Verk. Gent 1835 : Halte d'un cavalier devant un auberge où il parle à un villageois" en verk. coll. Wed. van Oosthuys van RijsenbukG-DE Jongh, 's Gravenhage i 8 Oct. i 847 „Een landschap doorsneden door eene rivier; over eene houten brug rijdt een wagen met een vroolijk gezelschap; in het verschiet zijn eenige boerenwoningen" (h. I el - 32 d., br. I el 68 d., D.).

Maar ook op nog andere wijze wist hij zijn zonnige landschappen te stoffeeren. In de coll. WINKLER te Leipzig was in I768 een dorpsgezicht met een troep bedelaars. Het was klaarblijkelijk verworven op de verk. coll. WiERMAN,

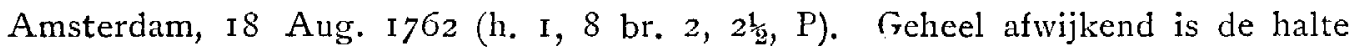
van jagers in het Museum te Rijssel, in $\mathrm{I} 88 \mathrm{I}$ te Parijs gekocht op verkooping der beroemde verzameling RoXARD DE LA SALLE uit Nancy. SALmon maakte er een ets naar voor den catalogus van deze collectie en een kleine houtsnede verscheen in de Gazette des Beaux-Arts (1881, I, p. 253). Dit stuk doet meer aan CuYp dan aan POTTER denken. Een prachtig landschapje bij den heer HOLFORD te Londen vertoont een boschrand, waar konijntjes rondspringen; het staat op naam van POTTER. En in de collectie UGgLAs te Forsmark in $Z_{\text {weden }}$ is een landschapje, afkomstig uit de collectie WAHRENDORF, waarin een kleine jongen een hond tegen een eend ophitst. Het is gemerkt: G. Campiruysen.

GoverT CAMPHUysen toont in zijne openluchtstukken een echte "pleinairist" te zijn. Voortreffelijk gaf hij het zonbeschenen Hollandsche landschap weêr, en mooi staan bij hem de figuren in de lucht. Zijne koeien zijn zwaarder 
dan die van PoTTER, in het algemeen zijn zijne figuren wat massief. Hij heeft een breede, krachtige toets, spaart de verf niet; maar nooit zijn zijne stukken zwart, ondoorschijnend. Zijne schaduwen zijn transparant en fijn. Op het landschap der WALLACE-collectie is de avondstemming fijn gevoeld en uitnemend weêrgegeven. De vraag ligt voor de hand of onze schilder op POTTER of deze op hem invloed heeft uitgeoefend. Een zekere overeenkomst tusschen hun werk is onmiskenbaar; van daar dat zoovele stukken van CAMPHUysen in POTTERs vervalscht zijn. In de Ermitage te St. Petersburg berust nog eene groote, heerlijke schilderij, in den Catalogus als PotTer vermeld (No. 1056) en afgebeeld, die volgens een onzer eene valsche handteekening van POTTER draagt, en wel een der beste zoo niet de beste schilderij van onzen Govert CAMPHUYSEN is. (BODE, die de schilderij ook kent en nauwkeurig bestudeerde, deelde dit gevoelen.) Het is een groot landschap met twee koeien aan een plas, waarbij mooi geboomte. Rechts een weg, waarop een jager op een wit paard, bijna identiek met den ruiter op het stuk der verzameling JoHNSON, wien een knecht een haas aangeeft. Een ander jager ligt op 't gras; bij hem een paar honden. Hoezeer deze schilderij als POTTER doet in photographie '), in werkelijkheid herinnert ons de zwaardere toets, het zeer sterke impasto en vooral de fijngrijze toon dadelijk aan CAMPHuysen.

Dit werk, dat hem tot POTTER's evenknie stempelt, zou ons doen vermoeden, dat POTTER bepaald sterken invlocd op CAMPHUYsEN gehad heeft. POTTER was wel ongeveer even oud, maar het is van hèm bekend dat hij zeer vroeg ontwikkeld, zeer vroeg een volleerd schilder was, terwijl wij dat van CAMPIIUIJSEN niet weten. Het vroegste jaartal op diens werk is 1645 , indien wij mogen vertrouwen dat de vervaardiger van den catalogus eener tentoonstelling in het Bethnal Green-Museum (1880) goed gclezen heeft. Dat zou nu-wel doen vermoeden dat ook hij reeds vroeg - 2 I jaren oud - rijp was. Maar geen onzer heeft dat jaartal kunnen controleren, noch kunnen zien of dit vroege werk reeds op de hoogte van zijn beste stukken staat.

Eene grocte overeenstemming tusschen beider werk bestaat; wellicht worden nog eens gegevens ontdekt, die hier meer licht verspreiden.

Reeds vermeldden wij zijn schilderij van den bruinen hond in het slot te Gripsholm. Zulke afzonderlijke dierstudiën komen meer van hem voor. In het museum te Kiel is bv. een broedende hen, gemerkt G. CAMPhUySEN (h. 72 br. I04, P.). Het was in 1878 naar Kiel gezonden door de directie van het museum te Berlijn, waar het in 1874 met de geheele collectie SuERMondt uit Aken gekomen was. SUERMONDT had het in 1864 voor $\mathrm{f}$ 125.- gekocht op de verk. coll. VAN CLEEF. Niet onwaarschijnlijk is het dezelfde schilderij „Een henne van

\footnotetext{
1) BRAUN vervaardigde er een zeer goeile reproductic van.
} 
Govert Camphuysen" die Dec. I669 voorkwam in den boedel van Ds. Josras Smith te Delft.

Dood wild vonden wij vermeld op de verk. coll. LANTINGHUSEN te Stockholm, 1857. Een stilleven met levensgroote figuren op den achtergrond werd door den heer W. GRUYTER ingezonden op de tentoonstelling van oude kunst te Amsterdam in I 867 (h. 108, br. I 56). En ten slotte signaleerde de heer GranbERG te Stockholm ons een zeestrijd tusschen Hollanders en Engelschen, gemerkt: CAMPHUIJSEN.

Het komt ons overbodig voor de vele schilderijen "met koetjes", de „boerekeuckens" of de ${ }_{n}$ schuyrtjes" alle op te sommen, die wij in oude inventarissen of in verkoopingscatalogi aantroffen, en willen slechts op een drietal opmerkzaam maken. In 1653 werd in den boedel van JEAN LE THOR te Amsterdam een "beerejacht van CAMphuijsEN" op $f$ I 8.- getaxeerd. De berenjacht van POTTER in het Rijksmuseum te Amsterdam komt ons hierbij natuurlijk weer aanstonds in de gedachte. In 1668 werd "De Prins te paerd, van CAMPHUyseN" toebehoorende aan Joanna Juliaens, weduwe van Willem Bogater te Amsterdam $\Gamma$ 48.- waard geacht. En bij de nalatenschap van Johannes Verspreet te Amsterdam 1656, taxeerde Ferdinand BOL „Een stuck van CuIjper opgemaakt door CAmphuysen" op $f$ 36. - Dit is vermoedelijk Hendrick Kuyper van wien omtrent dezen tijd meer landschappen in Amsterdamsche inventarissen voorkomen, doch wiens werk ons overigens onbekend is.

Er bestaat ook één ets van hem. Geheel op POTTER geïnspireerd gaf hij hierin een ietwat magere koe te zien, die naar rechts gewend vóór een boom slaat. Het zeldzame prentje, waarvan een exemplaar berust in 's Rijks Prentenkabinet te Amsterdam, is links bovenaan gemerkt G. CAMPhUijSEN.

Dat hij te Stockholm ook als portretschilder werkzaam is geweest, hebben wij boven reeds vermeld. De heer EICHHORN te Stockholm is of was eveneens in het bezit van een zijner portretten, voorstellende zekere EvA HORN. En in het Rijksmuseum te Amsterdam staat op zijn naam een in 1886 te Londen gekocht mansportret (h. II7 br. I04, D.) in de dracht van omstreeks I670 met de bijvoeging dat dit portret wellicht den schilder zelf voorstelt, omdat de voorgestelde een brief in zijn hand houdt waarop staat: „G. CAMPhUiJSEN tot Amsterdan', Dit duidt zonder twijfel den naam van den voorgestelde aan, uit niets blijkt evenwel dat deze de bekende schilder was. Daar er nu in dezen tijd werkelijk een naamgenoot woonde, doen wij voorzichtig, ook dezen mee te laten dingen als eigenaar van de gelaatstrekken in questie.

Deze andere GOvert CAMPhuYsen was de zoon van den schilder Jochem Camphuysen en was gehuwd met Lysbeth Cramers. Hij werd begraven te 
Amsterdam 30 Aug. I672, d. i. nog geen twee maanden na zijn neef den schilder, zij leetde nog in $\mathbf{1 6 7 8 . ~ U i t ~ d i t ~ e c h t p a a r ~ z i j n ~ v i j f ~ k i n d e r e n ~ g e b o r e n , ~ w a a r v a n ~ d e ~}$ oudste GodeFind in 1657 of 1658 te Amsterdam geboren is. Deze ondertrouwde te Amsterdam I4 Mei 1678 met Martyntje Reyniersdr. De Coetser, en liet eveneens vijf kinderen na, waarvan aan het jongste in 1686 geborene de oude familienaam DiRK gegeven werd.

Het verdient opmerking dat deze laatste Govert CAMPHUYSEN in een overigens onbelangrijke acte van 28 Juni 1678 , geteekend:

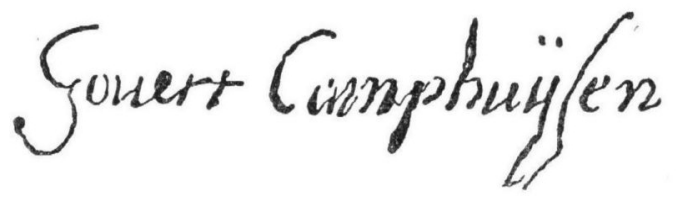

handelend over een pleiziertochtje in een chais naar Haarlem en omstreken genoemd wordt "Sr. GoverT CAMPhuysen, konstschilder" "). Aan hem is vermoedelijk toe te schrijven een Kersnacht in de manier van Cornelis Saftleven, maar veel zwakker, die eenige jaren geleden aan de directie van het Rijksmuseum te Amsterdam te koop is aangeboden, gemerkt: Godefricdus Camphuysex. Hij liet de kunst dan ook aan meer bevoegden over en in een acte van 24 Nov, I686 wordt GodEFridus CAMPIIUysen, wonende op den hoek van de Palmstraat, wijnkooper genoemd. ${ }^{2}$ ) In de kroeg kende hij klaarblijkelijk beter den weg dan in het atelier. De eerste druk van SALOMON vaN RuSTING's Vol-geestige werken (Amsterdam I685, bij JAN TEN. HOORN) bevat een "Opdracht aan mijn seer Goeden Vriend GoDeF. CAmpidomus". Hiermede kan niemand anders bedoeld wezen dan onze schilder-wijnkooper. Maar wij twijfelen er aan of de oude DrRCK RAFELSz. erg gesteld geweest zou zijn op dien na-neef, wanneer hij kennis had kunnen nemen van deze opdracht die begint:

O Vrind van Bacchus, en van al de nobele basen,

Die tieren bij de Vocht; en 't legen van de glasen."

Toen JAN TEN HOORN in $\mathbf{I} 693$ een vermeerderden druk bezorgde van hetzelfde prulschrift, was er een tweede opdracht bij „Aan mijn Seer Waarde en Broederlijke Vrind Godefridus CAMp-Huys".

Wanneer deze Godefridus CAMPHUYSEN gestorven is, is ons niet bekend geworden, evenmin of van zijn in I686 geboren zoon DIRK de schilder JAN KAMPHUIZEN afstamt, die in 1760 te Amsterdam geboren is en wiens zelfportret in het Rijksmuseum te Amsterdam hangt. Dat zoowel diens vader de timmerman

1) Prot. not. S. VAn Der Slujus te Amsterdam.

2) Prot. not. J. D'Amour te Amsterdam.

Oud-Holland, Igo3. 
DIRK KAMPHUIZEN als zijn twaalf jaren jongere broeder de beroemde acteur DIRK KAMPHUIZEN den ouden familienaam droegen zou hier wel voor pleiten, maar daartegen moet gezegd worden dat deze KAMpHuizens stellig KoomschKatholiek waren.

Wordt nog eenmaal de aansluiting gevonden tusschen de CAMPHUYsENS en de KAMPHUIZENS dan zal vermoedelijk ook aangewezen kunnen worden wie de onderteekenaar geweest is van de volgende quitantie, in 's Rijks Prentenkabinet te Amsterdam berustende:

"Ontvangen van Mijn Heer den Heer Houschooven de somma van twee en veertig guldens voor het schilderen van drie Portraiten voor UEd. Voldaan den Ige Februarij I770

\section{G. KAMPHUISEN."}

Om ten slotte nog iets te zeggen over de niet bestaan hebbende CAMP. HUysens zij er op gewezen dat de P. T. Camphursen van KRamm zijn ontstaan te danken heeft aan een verkeerde lezing van de naamteekening op het stuk te Kopenhagen, en dat de HERMAN CAMPHUYSEN van denzelfde verklaard wordt door de mededeeling van Fuessli (ed. 1779, p. 338) die gewag maakt ván "Herman von Kampfhausen, Mahler zu Hamburg um 1670 , der als Lehrmeister des Christian Bernetz bekannt ist."

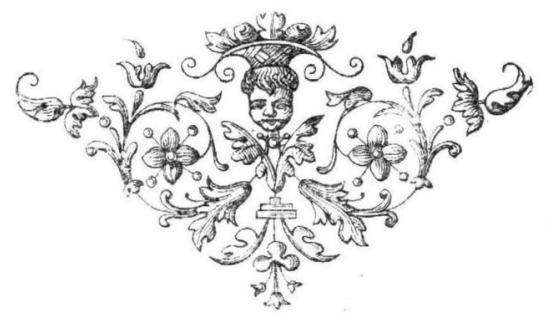




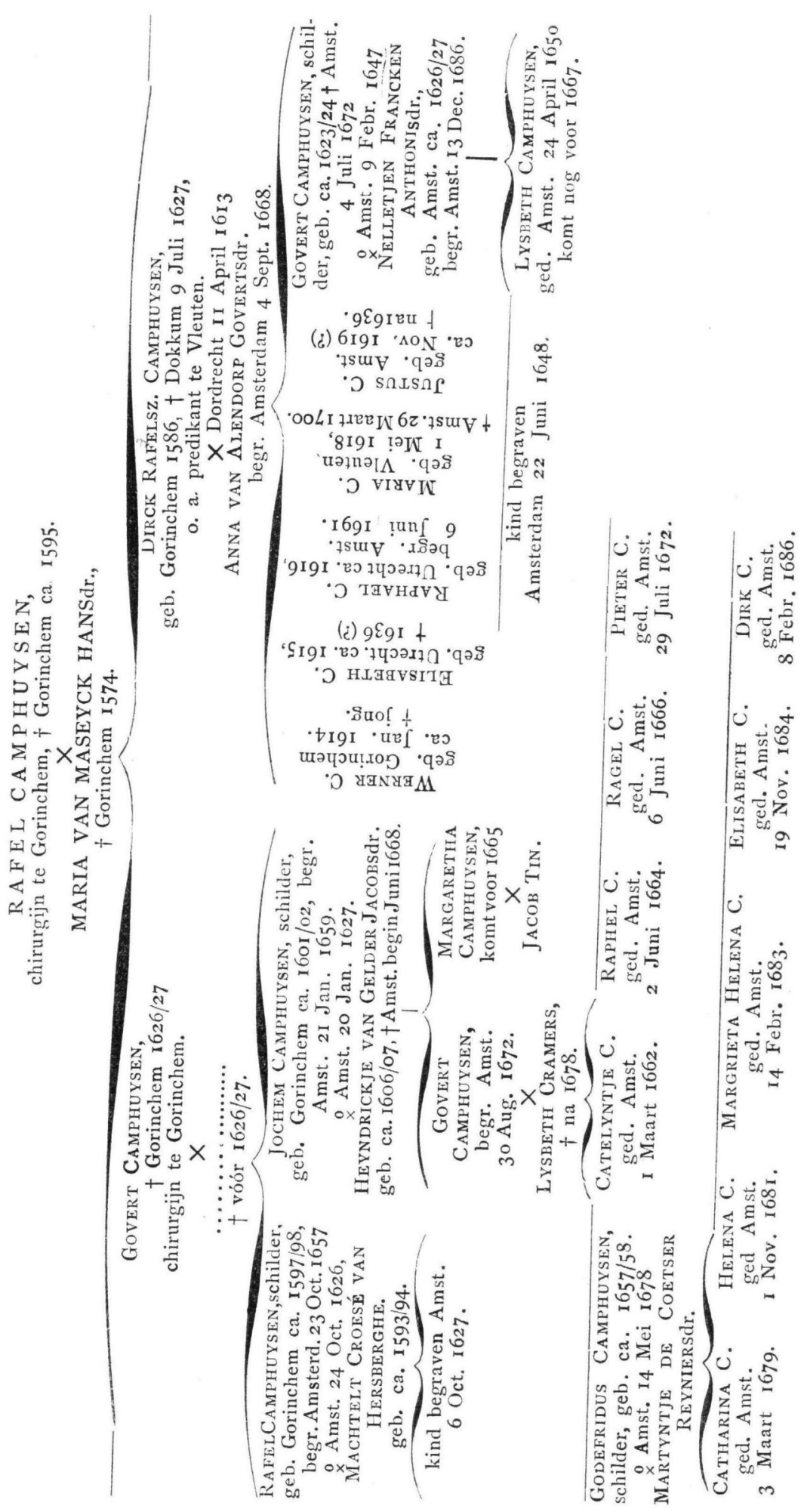

